\title{
Social Entrepreneurship in Serbia: The State of Play
}

\author{
DRAGAN GOLUBOVIĆ * \\ BELA MUHI \\ Educons University \\ Sremska Kamenica \\ Vojvodina, Serbia
}

\author{
Review paper \\ UDK: 36:65.012(497.11) \\ doi: $10.3935 /$ rsp.v26i3.1564 \\ Received: June 2018
}

This paper takes stock at key policy issues underpinning the development of social entrepreneurship in the Republic of Serbia. It consists of four chapters. Chapter 1 provides the general context of the paper. It sets out the general policy context and discusses the roots of social entrepreneurship in Serbia, as well as the perceived policy factors which have facilitated its development in the last decade. The general findings of the first official survey on social enterprises in Serbia are also discussed in this chapter. Chapter 2 examines the legal framework governing or impacting on social entrepreneurship. It first provides a critical overview of the framework regulation for enterprises for employment and professional rehabilitation of persons with disabilities, civil society organisations (CSOs) and social cooperatives, respectively. Thereafter, it proceeds with the analyses of pertinent tax law and the legal framework for public financing of CSOs, as well as the legal and policy framework for social service provision. An analysis of the legal framework for volunteers concludes this chapter. Chapter 3 presents the results of the first pilot survey on social enterprises in the Autonomous Province of Vojvodina (Vajdaság Autonóm Tartomány), which was conducted in 2016. Conclusions on the state of play of social entrepreneurship in Serbia, including measures which could conceivably facilitate its further development, are presented in Chapter 4.

Keywords: social entrepreneurship, social enterprises, civil society organisations, enabling legal environment, survey on social enterprises.

\section{GENERAL CONTEXT}

The concept of social entrepreneurship has been the subject of vigorous scholarly debate for the last several decades. This debate was largely sparked by the crises of the welfare state and a failure of the private sector to fill in the resulting gap in social service provision, in particular for the un- derprivileged (Joppke, 1987; Sandmo, 1995; Castles, 2004). This development prompted scholars and policy makers to revisit the relationship between the voluntary (not-forprofit) sector and the state; it also facilitated the emergence of new institutional tools of choice to pursue economic activities with social goals (Borzaga, Defourny, 2001;

\footnotetext{
* Dragan Golubović, Educons University / Univerzitet Educons, Vojvode Putnika 85-87, 21208 Sremska Kamenica, Vojvodina, Serbia / Srbija,dragan.golubovic@educons.edu.rs
} 
Thomas, 2004; Defourny, Nyssens, 2010). It should be noted, however, that the concept of social entrepreneurship is not universally embraced. Critics of the concept argue that it is poorly articulated and thus does not provide a clear-cut answer as to whether it has to do with the application of sound business principles to the not-for-profit sector, or whether it offers a radically different approach to the business of doing good. There is also a lack of clarity, critics argue, as to the precise meaning of entrepreneurship in the notion of social entrepreneurship. Some of those conceptual problems arguably stem from the fact that the concept is driven by ideology, rather than sound policies, and is primarily concerned with ensuring state aid, tax breaks and public support for its actors, rather than with offering sustainable solutions for social problems (Münkner, 2005; Peredo, McClean, 2006; European Commission, 2016). With respect to the latter, it was argued that solving systemic social problems requires an enhanced interaction between citizens and democratic institutions, in order to make the government better fulfil its responsibilities, rather than private action in the way of social entrepreneurship; the latter lacks capacity to ensure lasting social changes (Ganz, Kay, Spicer, 2018).

In addition, differences of opinion persist with respect to the defining characteristics of social enterprises (Borzaga, Defourny, 2001; KMFA, 2007; Monzón, Chaves, 2012; Ferreira, Fernandes, Peres-Ortiz, Alves, 2017). Thus, a recent survey conducted in the European Union Member States ('EU') and Switzerland reveals that twenty countries have a national definition of social enterprise ('SE'), however, in six of these countries the definition does not require SE to have an inclusive (democratic) governance. Likewise, in several of the remaining nine countries which do not have a national definition of SE, inclusive governance is not perceived as a defining characteristic of SE (Wilkinson, 2015).

The Organisation for Economic Cooperation and Development (OECD) and the European Commission define social entrepreneurship as the entrepreneurship "that has as main goal to address pressing social challenges and meet social needs in an innovative way while serving the general interest and common good for the benefit of the community.... social entrepreneurship targets to social impact primarily rather than profit maximisation in their effort to reach the most vulnerable groups and to contribute to inclusive and sustainable growth". On the other hand, within the framework of its Social Business Initiative - SBI, the European Commission defines a SE as "an operator in the social economy whose main objective is to have a social impact rather than make a profit for their owners or shareholders. ${ }^{2}$ It operates by providing goods and services for the market in an entrepreneurial and innovative fashion and uses its profits primarily to achieve social objectives. It is managed in an open and responsible manner and, in particular, involves employees, consumers and stakeholders affected by its commercial activities". In the EU parlance the terms social entrepreneurship, social economy, social solidarity economy, and social business are often used interchangeably. However, while these terms do have lots in common, they do not necessarily overlap. It is thus argued that the practice of using different terms to describe social

\footnotetext{
${ }^{1}$ http://www.oecd.org/cfe/leed/social-entrepreneurship-oecd-ec.htm; accessed on February 1, 2018.

${ }^{2}$ European Commission (2011). Social Business Initiative Creating a favourable climate for social enterprises, key stakeholders in the social economy and innovation (SEC(2011) 1278 final, p. 2. Available at http:// ec.europa.eu/transparency/regdoc/rep/1/2011/EN/1-2011-682-EN-F1-1.Pdf; accessed on February 1, 2018.
} 
entrepreneurship does not facilitate efforts to reach the common understanding of its underlying principles (Hudson, 2009; European Commission, 2016).

With this background, social entrepreneurship in Serbia - albeit in a very rudimentary form - can be traced as early as in 1948 when the first enterprises which employed persons with disabilities and facilitated their social inclusion were established; in Macedonia, such enterprises were first established in the 1960s (Dokmanović, Koevski, Spasovski, 2016). In recognition of their social role, those enterprises were subsidised and enjoyed other corresponding benefits. Despite being in state ownership, they did share some remote similarities with their contemporary counterparts. On one hand, they shared some of the features of social cooperatives type " $B$ " in Italy in that they were membership organisations based on solidarity, established to pursue specific social goals, rather than generate profits, in which workers had limited decision making power (Thomas, 2004; Borzaga, Poledrini, Galera, 2017). On the other hand, their employment structure (only persons with disabilities) resembled sheltered workshops (Spear, Bidet, 2005). However, it was not until the last decade that the concept of social entrepreneurship came prominently into the fora of public policy. This development was facilitated by the government's efforts to open a market for social service provision, as well as develop an enabling legal environment for civil society organisations ('CSOs'). ${ }^{3}$ While these reform efforts were not necessarily planned and implemented in sync, the reform of CSOs framework legislation has conveniently expended a menu of institutional tools of choice available to pursue economic activities with social goals (Chapter 2). The process of EU integration, which Serbia has embarked on in earnest only since $2013,{ }^{4}$ has also played a positive role in promoting social entrepreneurship. The EU Instrument of Pre-Accession Assistance-IPA ${ }^{5}$, as well as donors' bilateral assistance have provided the necessary technical and financial support towards that end. Among others, Serbia is eligible to participate in the EU Employment and Social Innovation Programme-EaSI 20142020, which promotes microfinancing and social entrepreneurship. ${ }^{6}$ In addition, the international development agency of the Federal Republic of Germany, Deutsche Gesellschaft für Internationale Zusammenarbeit - GIZ, in collaboration with the Ministry of Sport and Youth, is providing an ongoing technical support to SE which target unemployment of youth, including youth belonging to vulnerable social groups.?

The first comprehensive survey of SEs, which was conducted by the Statistical Office in 2012, revealed that there were 1,196 SEs operating in Serbia. The Survey drew on a definition of SE as set out in the European Commission's Social Business Initiative and thus included enterprises for

\footnotetext{
${ }^{3}$ In this paper the term civil society organisations (CSOs) refers to any institutional form of choice which meets the following criteria: a) it is a voluntary organisation; b) it is established by an instrument of private law (contract, act on establishment), rather than by virtue of law or government's decisions; c) it is established to pursue not-for-profit goals deemed in mutual or public benefits; and, d) it is separated from the government structure. In the context of Serbia, the term entails associations (membership organisation), foundations and endowments (non-membership organisations). The terms public benefit goals, public benefit purposes and activities and social goals, social purposes and activities are used in the paper interchangeably.

${ }^{4}$ On June 26, 2013 the European Council approved recommendation of the European Commission for the European Union (EU) to open membership negotiations with Serbia.

${ }^{5} \mathrm{http}$ ://ec.europa.eu/regional_policy/en/funding/ipa; accessed on May 5, 2018.

${ }^{6} \mathrm{http}: / /$ ec.europa.eu/social/main.jsp?catId=108; accessed on March 3, 2018.

${ }^{7}$ http://odskoledoposla.org/o-projektu; accessed on February 25, 2018.
} 
professional rehabilitation and employment of persons with disabilities (45), cooperatives (785), associations (283), foundations (23), development agencies (32), business incubators (18), spin-off enterprises (8), and others (2). ${ }^{8}$ These undertakings employed 10,326 workers altogether and generated 6.8 billion RSD, accounting for $0.2 \%$ of Serbian GDP in that fiscal year. Almost two thirds of surveyed SEs operated as mutual cooperatives; at the time, a social cooperative was not recognized as distinct institutional form (Chapter 2). The dominance of (mutual) cooperatives in the survey explains why in most cases the stated objective of SE included economic empowerment of their members and generating new jobs. The survey also found that SEs which operated as CSOs (associations and foundations) generated most of their income from education and training (31.0\%), tourism, accommodation, food-related services and catering (18.0\%), and culture and arts (11.8\%). Cooperatives generated their income mostly from trading agricultural commodities $(61.9 \%)$, producing those commodities $(36.8 \%)$, and wholesale and retail (23.8\%). Enterprises for professional rehabilitation and employment of persons with disabilities generated most of their income from printing and copying (28.9\%), manufacturing of clothes and footwear $(20.0 \%)$, and manufacturing of furniture $(17.8 \%)$. Other types of SEs generated their income mostly from education and training (58.3\%), administrative services, bookkeeping and accounting $(13.3 \%)$. The large share of services in the overall income of CSOs was credited to the fact that engaging in those services did not necessarily require significant financial investment. Rather, CSOs seemed to have been able to utilise their otherwise skilled staff to tap into the market for those services
(Statistical Office of the Republic of Serbia, 2014; Golubović, Galetin, 2015).

\section{THE LEGAL FRAMEWORK FOR SOCIAL ENTREPRENEURSHIP}

The legal framework governing or impacting on social entrepreneurship in Serbia is scattered in the hosts of framework, tax and other regulation. Thus, the Law on Professional Rehabilitation and Employment of Persons with Disabilities ("Official Gazette of the Republic of Serbia" - OGRS, No. 36/09, 32/13 - 'Law') provides that an undertaking whose stated goal is employment and betterment of quality of life of persons with disabilities can be established as an enterprise for professional rehabilitation and employment of those persons, a sheltered workshop, a "social enterprise", and a "social organisation" (Art. 34). The Law introduces a set of policy measures to hone the working skills of people with disabilities and encourage their employment with a view of improving their social inclusion (Art. 13). It also envisages various state aid schemes in support of enterprises for professional rehabilitation and employment of persons with disabilities and sheltered workshops (Art. 30-33). Furthermore, the Law introduces a mandatory quota for the employment of those persons relative to the overall number of employees in a regular commercial company (Art. 24). The Law defines a SE as "a corporation which is established with a view of addressing the needs of persons with disabilities and which employs at least one such a person" (Art. 45). A social organisation, on the other hand, is deemed "an undertaking other than a social enterprise which is established to pursue activities geared at addressing the needs of persons with disabilities, and

\footnotetext{
${ }^{8}$ There is a lack of clarity in the survey as to the precise meaning of 'business incubators' and 'development agencies'. The notion of 'spin off enterprises' refers to business undertakings which are established by CSOs-social enterprises, in furtherance of their social goals.
} 
which employees at least one such a person" (Art. 45). A SE and social organisation are required to designate part of their profits to support the working and other conditions of employees with disabilities. The Law does not set out the minimum percentage of profits which must be designated for those purposes - nor does it envisage sanctions in case of violation of the profit distribution requirement (Golubović, Galetin, 2015).

The definition of a SE and social organisation in the Law gives rise to several issues. First, the Law provides very few distinctive features of these institutional forms and therefore the underlying differences between the two remain blurred. In particular, while they seem to share the same objectives, the ensuing advantages of choosing one form over the other in pursuing their (narrowly) defined social goals do not seem clear. In addition, a definition of the SE in the Law is narrowly construed and likened to providing support and creating employment opportunities for persons with disabilities only. Thus, the Law falls short of recognising the role social entrepreneurship can play in providing support and employment opportunities to other vulnerable groups. Likewise, the Law falls short of recognizing the role social entrepreneurship can play in other areas deemed in public interest which are not necessarily associated with the employment of vulnerable groups and their social inclusion. For example, the Slovenian Law on Social Entrepreneurship ("Official Gazette of the Republic of Slovenia”, No. 20/2011, 13/2018) provides that a SE may be established in order to pursue a broad scope of activities deemed in public interest, ranging from providing support and creating employment opportunities for persons with disabilities and other vulnerable groups (the longer term unemployed, the elderly, the Roma, minors who did not complete primary education and former convicts) related to organic food production, nature conservation, landscaping, animal protection, promotion of the use of renewable energy sources and the development of the green economy, social tourism, protection and rescue activities, promotion of local communities' development, and support services for SEs, among others (Art. 5, 6).

The foregoing issues are reflective of challenges which are likely to arise when a definition of SE is provided in a law whose underlying objective is catering to the needs of a particular social group. This policy approach carries an inherent risk of the concept of SE being more "social", rather than "entrepreneurial", which may impact adversely on the long-term sustainability of SE (Golubović, Galetin, 2015). As the comparative experience suggests (Italy, Slovenia, Spain), insofar as there is a legal definition of SE, it is better suited to be a part of the framework regulation governing SE, rather than a law targeting particular social groups (Defourny, Nyssens, 2010; Kerlin, 2010; Golubović, 2012; Wilkinson, 2015).

The Law on Associations (OGRS, No. 51/09, 99/11 - 'Law') provides that an association may be established by at least three legal or natural persons, in order to pursue not-for-profit goals deemed in mutual or public interest (Art. 10). An association may engage directly in economic activities under the following conditions: (1) the activities are related to the organisation's not-for-profit purposes as set out in its bylaws; (2) the activities are envisaged in the organisation's by-laws; (3) the activities are "incidental" or carried out in "frequency" which is deemed necessary for the support of the organisation's not-for-profit purposes; (4) the activities are registered with the Commercial Registry (Registry); and (5) the surplus generated from the activities is used to pursue the organisation's not-for-profit goals only (Art. 37). The Law provides that the organisation must enter into the Registry only a "major" related economic activity, pursuant to its by-laws. Neverthe- 
less, it is free to engage in any other related economic activities it sees fit. In practice, however, the supervising public authority has occasionally taken the position that an association may directly engage only in the registered economic activity. Fines are levied on the association and its director if it is found in breach of the foregoing requirements (Art. 73).

The foregoing provisions give rise to several issues. First, the Law does not define the notion of economic activity - nor does it refer to other legal sources which might entail such a definition. As a result, it is not clear whether the notion pertains to sale of goods and services which an association carries steadily and in greater frequency, or whether it also entails the organisation's fund-raising and other occasional economic activities. In addition, the distinction between related and unrelated economic activities is often blurred in practice and not easy to establish (EFC, 2015). The Law does not provide any further guidance on this issue, which poses a challenge for its fair and consistent implementation. Likewise, the Law does not provide any further guidance as to the permissible scope of related economic activities, i.e. what is the precise scope of the association's direct economic activities which is deemed not to exceed the "incidental" threshold. The lack of clarity with respect to the alternative threshold requirement - that is, the scope of related economic activities which can only be carried in frequency deemed "necessary" to support the organisation's not-for-profit purposes, also gives rise to concerns. The ill-conceived constraints on the permissible scope of association's economic activities, coupled with the prescribed fines, give the supervisory authority a great deal of un- warranted discretionary power and thus discourage associations - including those which regard themselves SE - to engage directly in economic activities.

Pursuant to the Law on Foundations and Endowments (OGRS No, 88/10, 99/11 - 'Law'), a foundation and an endowment may be established by a natural or legal person. A foundation may be established to pursue not-for-profit goals which are deemed in public interest, while an endowment may be established to pursue both public and private interest goals (Art. 2, 10). However, an endowment established to pursue private interest goals may not directly engage in economic activities (Art 45). The conditions envisaged for a foundation and endowment to engage directly in economic activities are similar to the ones set out in the Law on Associations and therefore do not merit separate consideration (Art. 45). It is noteworthy, however, that the perceived shortcomings in the rules governing conditions for CSOs to engage directly in economic activities can partly be ascribed to the lack of a single 'European' regulatory approach towards this issue that can be conveniently imported into the national legislation (EFC, 2015).

The new Law on Cooperatives (OGRS, No. 115/15 - 'Law') envisages a social cooperative as a distinct institutional form. Rather than pursuing mutual interests of its members, a social cooperative may be established in order to facilitate social, economic and work integration of vulnerable social groups, or pursue goals deemed in the "interest of local community". The notion of vulnerable social groups is broadly defined so as to include persons in social needs per law governing social protection, as well as those who are protected pursuant to law

\footnotetext{
${ }^{9}$ The Law generally defines a cooperative as a legal entity which is established by five or more natural persons who run the organisation on the basis of cooperative principles and in the mutual interests of its members (Art. 2, 15).
} 
governing prohibition of discrimination. ${ }^{10}$ A social cooperative is obliged to designate at least a half of the surplus generated from economic activities for the pursuit of its stated social goals (Art. 10). The surplus is taxed at a standard $15 \%$ profit tax rate (Art. 1, 39, Corporate Income Tax Law).

At present, there are no particular tax benefits or restricted tender procedures available to social cooperatives. While providing tax breaks for social cooperatives is not necessarily the right avenue to proceed in order to foster their development (Landin, 2009), the EU Directive on Public Procurement (2014/24/EU) does provide an opportunity to stimulate the growth of social cooperatives - or for that matter other SE - by virtue of restricted tender procedures. Thus, the Directive allows the contracting authority to restrict some tendering procedures for the purchase of some goods, works or services to sheltered workshops and economic undertakings whose main aim is work integration of persons with disabilities and other vulnerable (disadvantaged) persons. It also provides an opportunity for certain bids to be evaluated not only on the basis of economic considerations, but also on the basis of various social and environmental considerations (European Commission, 2010; Aikaterini, 2017). However, a national policy with respect to the restricted tender procedure needs to be mindful of the limits set out in the jurisprudence of the European Court of Justice in this respect. ${ }^{11}$

Overall, the introduction of a social cooperative as a distinct institutional form is a positive development. It is in tune with the best comparative practices which suggest that a plurality of legal forms has a positive impact on the development of social entrepreneurship (Münkner, 2005; Chaves, Monzón, 2005; KMFA, 2007; Wilkinson, 2015).

The Corporate Income Tax Law (OGRS, No. 25/01), which was most recently amended in 2017 (OGRS, No. 113/17 - 'Law'), generally exempts CSOs from profit tax. In addition, income generated from CSOs' economic activities is exempt from the profit tax if the following conditions are met: a) annual "surplus" generated from the organisation's economic activities does not exceed 400,000 RSD (3,400 EURO); b) earnings were not distributed to the founders, employees, members of the management board, or any affiliated person thereof as defined by the Law; c) salaries for the members of the management board and employees do not exceed double the average salary paid by organisations engaged in the same activities in the commercial sector; d) all earned income was used to further the objectives for which the organisation was created; and, e) the organisation's economic activities do not give rise to unfair competition with the private business sector, as defined by the antitrust law (Art. 44). The annual surplus exceeding the prescribed monetary threshold is taxed at a regular $15 \%$ profit tax rate.

Corporations may deduct up to $5 \%$ of their gross income for health care, cultural, cinematography, educational, scientific, humanitarian, religious, environmental protection and sport-related purposes, as well as for "social service providers" established pursuant to a law governing social protection (Art. 15). ${ }^{12}$ The list of public benefit purposes is exhaustive (numerus clausus) and therefore donations to purposes other

\footnotetext{
${ }^{10}$ The Law prohibits discrimination on the basis of race, colour, citizenship, national and ethnic violation, language, religious and political conviction, sex and sexual orientation, well-being, health, physical ability, marital and family status, age, prior convictions for crimes and felony, physical traits, membership in political trade union and other organisations as well as other real or presumed personal traits. (Art. 2, the Law on Prohibition of Discrimination).

${ }^{11}$ Case C-559/12 P French Republic v European Commission ECLI: EU: C: 2014:217.

${ }^{12}$ The Personal Income Tax Law does not provide tax deductions for donations by natural persons-tax payers. While this approach runs counter the European best practices, given low personal income base, it is not likely that tax deductions alone would provide significant incentive for individuals' charitable giving.
} 
than those specifically referenced in the Law are not eligible for deductions.

The Law gives rise to several issues which may impact adversely on CSOs that regard themselves SE. First, it provides limited incentives for giving to CSOs which operate as SE type "B" (employment and betterment of vulnerable groups). It recognises as tax deductible only donations to social service providers - that is, public institutions and CSOs which provide "formal" social services (those which are on the list of recognised social services as provided by law). However, it falls short of recognising CSOs which provide "informal" social services (those which are not on the recognised services list) as eligible recipient of tax-exempt donations. In addition, the Law falls short of recognizing hosts of public benefit purposes which otherwise fall within the remit of a SE type "A". This is due to the fact that the list of public benefit (social) purposes for which donations are exempt is narrowly construed and not aligned with the non-exhaustive list of public benefit purposes/activities in the Law on Associations. ${ }^{13}$ As already noted, the Slovenian Law on Social Entrepreneurship broadly defines goals in which SE type "A" may engage. In addition, the list of social goals in this law is not exhaustive, as a separate law may envisage other goals for which a SE type "A" may be established (Art. 5). Likewise, the Italian Law on Social Enterprises (Legislative Decree, $n^{\circ}$ 155 of 24 March 2006) provides that a SE type
"A" may be established to pursue instruction and professional training, social tourism, academic and post-academic education, research and delivery of cultural services, extra-curricular training, and support to SE, among others (Art. 2). However, under the Serbian Corporate Income Tax Law donations to a CSO which pursues a majority of the foregoing goals are not eligible for exemptions. This restrictive regulatory approach impedes the financial sustainability of a SE type "A".

In addition, the Law is silent on a number of issues relating to donations for qualifying (public benefit) purposes which may adversely impact on CSOs which operate as SE. This includes: the lack of clarity as to whether donations in real estate are eligible for deductions $;{ }^{14}$ whether donations in the form of institutional grants are also eligible for deductions; and whether a CSO may carry over a donation to another fiscal year.

Overall, the perceived shortcomings in the Law, including the lack of clarity on the foregoing issues, are not conducive to efforts to utilise the concept of corporate social responsibility for the promotion of social entrepreneurship (Baron, 2007; Cornelius, Todres, Jivraj, Woods, Wallace, 2008; Niño, Silva, 2015).

The Regulation on Financing and Co-financing of Programmes Deemed in Public Interests Implemented by Associations (OGRS, No. 16/2018) ${ }^{15}$ sets out procedure

${ }^{13}$ Pursuant to the Law on Associations, an association which is established to pursue purposes deemed in public benefit is eligible to apply for public funds. The list of public benefit purposes in the Law entails: social security; care for disabled war veterans; care for persons with disabilities; social child care; care for internally displaced persons and refugees; assistance to senior citizens; health care; protection and promotion of human rights; education; science; culture; environmental protection and sustainable development, as well as other activities deemed in public interest (Art. 38, Law on Associations).

${ }^{14}$ According to the Opinion of the Ministry of Finance, tax exempt donations entail giving in money, goods and services, but not real estate (Opinion No. 011-00-76/2017-04 of July 12, 2017), however, the legal basis for such reading of the Corporate Income Tax Law does not seem clear.

15 The Law on Associations provides for a broad and non-exhaustive list of public benefit goals/activities, which includes: social security; care for disabled war veterans; care for persons with disabilities; social child care; care for internally displaced persons and refugees; assistance to senior citizens; health care; protection and promotion of human rights; education; science; culture; environmental protection and sustainable development, as well as other activities deemed in public interest (Art. 38, Law on Associations). Promoting social entrepreneurship is not deemed public benefit activity per se. 
and criteria for public financing and co-financing of programmes which are implemented by associations. Like its predecessor, the Regulation unduly discriminates against foundations and endowments which pursue public interests and therefore an association which is, for example, established to provide material and other support to the needy is eligible to apply for public funds, whereas a foundation or an endowment pursuing the same goal is not. This practice runs counter to the provisions of the Law on Endowments and Foundations which specifically provides that the criteria for public fund distributions which are set out for associations will apply accordingly to foundations and associations (Art. 46.).

The Law on Social Protection (OGRS, No. 24/11- 'Law') permits CSOs to be licensed for social service provisions which otherwise fall within the remit of responsibility of central and local government (Art. 1). Thus, at least in theory the Law has levelled the playfield for public institutions and CSOs as formal social services providers. In 2016, the Government approved the Employment and Social Reform Programme ESRP, which set out a framework for policy development in the area of employment and social protection, in order for Serbia to meet the EU requirements in these areas. The ESRP specifically notes the role of CSOs as social service providers and recognises their contribution as chief "innovators" in the market of social services. It calls for a new strategy on social protection to be developed, in order to create a more enabling environment for CSOs as social service providers; this document is currently under preparation. In 2016 the Government also adopted the implementing regulation, which provides the necessary financial framework for social service provision.

While those policy developments are encouraging, there is a lack of proper data collection which would measure their pre- cise impact on liberalisation of social service provision. In addition, there is a need for ongoing capacity building measures, in order for CSOs to gain a stronger foothold in the social service market, in particular at the local level (Centre for Liberal Democratic Studies, 2013).

Under the Law on Volunteers (OGRS, No. 36/10 - 'Law'), volunteering as an activity which an individual carries by free will and without any consideration (pro bono), in the interest of the public or the needy (Art. 2.). However, despite the foregoing definition, the Law regards volunteering a sui generis form of labour relationship, rather than a free will and participatory activity. Inter alia, the Law provides that a host organisation (which may be a public institution, a CSO and, if specific conditions are met, a corporation) shall enter into a written agreement with a volunteer in case of a longer term volunteering, or at the request of a volunteer (Art. 15); prohibits any kind of volunteer activities (ad hoc or longer term) below the age of 15 (Art. 11); requires that a host organisation cover the volunteer's insurance against injuries and professional diseases for longer term volunteer activities, irrespective of the nature of those activities and the perceived risks they might entail - and irrespective of whether a volunteer wishes to be insured (Art. 27); requires that a host organisation keeps records of all volunteers, including those involved in ad hoc volunteer activities (Art. 28); and, requires that a host organisation submits an annual activity report to the ministry responsible for labour and social protection, irrespective of whether it was a recipient of public funds (Art. 30). Hefty fines are levied on a host organisation and its representative for the breach of any of the foregoing obligations (Art. 32).

Overall, the Law renders volunteer activities prohibitively expensive for a host organisation and thus prevents CSOs from 
fully utilising volunteering in furtherance of their social goals (Golubovic, Galetin, 2015). The fact that the Law was enacted without the prior impact assessment analyses gives rise to the questions to whether this legislative initiative would have sustained closer scrutiny, given that general rules of civil law (including those governing responsibility for damages incurred in the course of volunteer activities) are otherwise applicable to volunteer activities. Indeed, the first comprehensive study on volunteering in the EU could not establish a correlation between a specific regulation on volunteering and a level of volunteer activities in the Member States. To the contrary, the study revealed that some of the countries with the highest percent of volunteers engaged (Sweden, the UK, the Netherlands, Denmark) do not have specific legal frameworks for volunteering (GHK, 2010).

The aforementioned problems with the Serbia volunteer legislation need to be viewed against the fact that volunteering is potentially an important source of income for CSOs which consider themselves a SE (Byrne, O’Shaughnessy, 2004; Wilkinson, 2015; O'Connor, Baker Rachel, 2017). The previously referenced 2012 survey on SE conducted by the Statistical Office revealed that SE engaged 23,836 volunteers. Associations engaged most of the overall number of volunteers $(91.1 \%)$, followed by foundations (7.4\%), cooperatives (1.3\%), and enterprises for employment of persons with disabilities $-0.2 \%$ (Statistical Office of the Republic of Serbia, 2014).

\section{THE SURVEY OF SOCIAL ENTERPRISES IN VOJVODINA}

In 2016 the first pilot survey on SE was carried in the Autonomous Province of Vojvodina (Vajdaság Autonóm Tartomány). ${ }^{16}$ The survey covered members of the "Coalition of Social Enterprises", which was at the time the only coalition of SE in Vojvodina. The underlying purpose of the survey was threefold: (1) to find out how SE in Vojvodina understood the concept of social entrepreneurship; (2) to identify major sources of SE income; and, (3) to identify the perceived major challenges which impede sustainability of SE. Altogether, out of 103 members of the coalition, $37 \mathrm{SE}$ responded to the questionnaire which was the basis of the survey: 21 associations; 11 enterprises for professional rehabilitation and employment of persons with disabilities; 2 mutual cooperatives; 2 spin-off enterprises; and, 1 foundation (Figure 1).

As compared to the 2012 survey (Chapter 1), the number of SE which participated in the survey was indicative, rather than representative, and therefore the analyses of the received data warranted caution. Nevertheless, the small number of foundations which participated in the survey might suggest that social entrepreneurs are privy to the problems associated with the foundation's limited access to public funds, given that the regulation governing distribution of public funds to CSOs pertains to associations only (Chapter 2). On the other hand, the absence of social cooperatives in the survey might suggest that there are still

${ }^{16}$ The survey, which was carried from October through December 2016, was part of the project: "Examining conditions and potential for development of social entrepreneurship as an instrument of social inclusion in the Autonomous Province of Vojvodina", implemented by the Educons University and funded by the Government of the Autonomous Province of Vojvodina (project No. 142-451-3665-2016-02). The authors participated in the survey in their respective roles as a Team Leader (Dragan Golubović) and a member of the project and research team (Bela Muhi). 
very few SE which have utilised this institutional form. Finally, the absence of social enterprises and social organisations in the survey, which the Law on Professional Rehabilitation and Employment of Persons with Disabilities envisages as distinct institutional forms, might suggest that these ill-conceived tools of choice have not taken hold in practice (Chapter 2). disabilities - EEPD (11). SE engaged in economic empowerment and employment of other vulnerable groups- EEVG came second (10), followed by SE engaged in organic agriculture (6), social service provision (5), social tourism (3), environmental protection (2), and technical support to SE (1). Out of $5 \mathrm{SE}$ engaged in social service provision, the majority (3) engaged in the

Figure 1

Institutional forms of surveyed SE

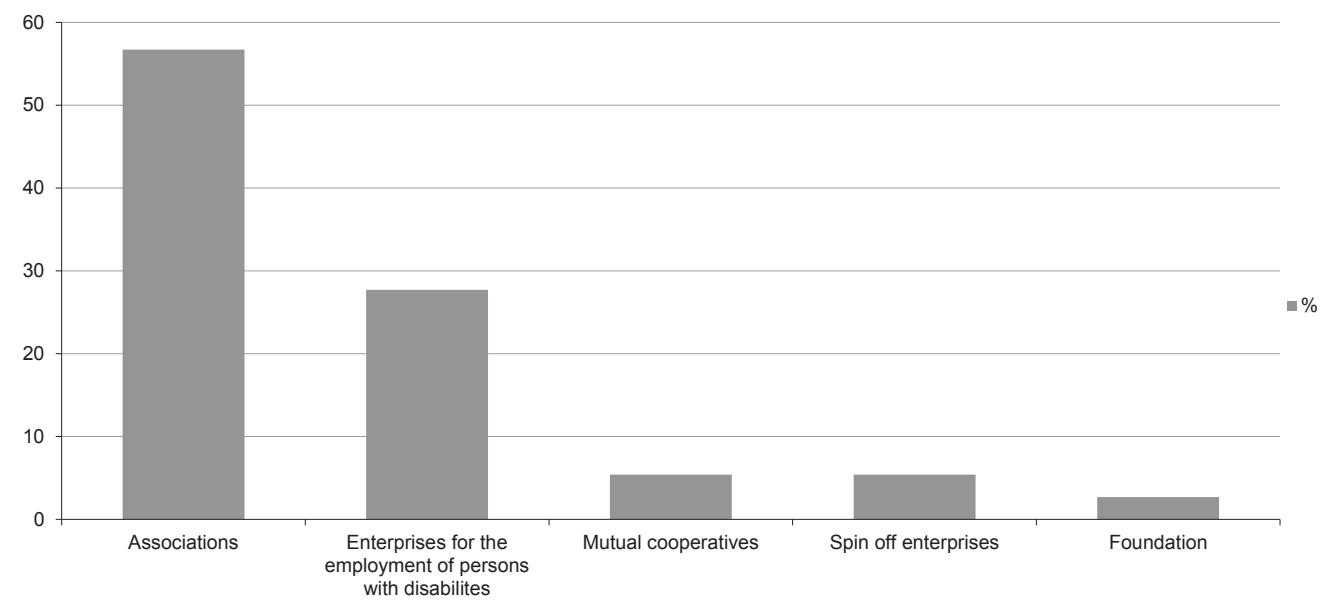

Source: Author's calculations.

As for the areas of their respective activities, most of the SE surveyed were enterprises engaged in professional rehabilitation and employment of persons with so called informal social service provision i.e. those which fall out of the list of social services recognized by law. 
Figure 2

SE areas of activities

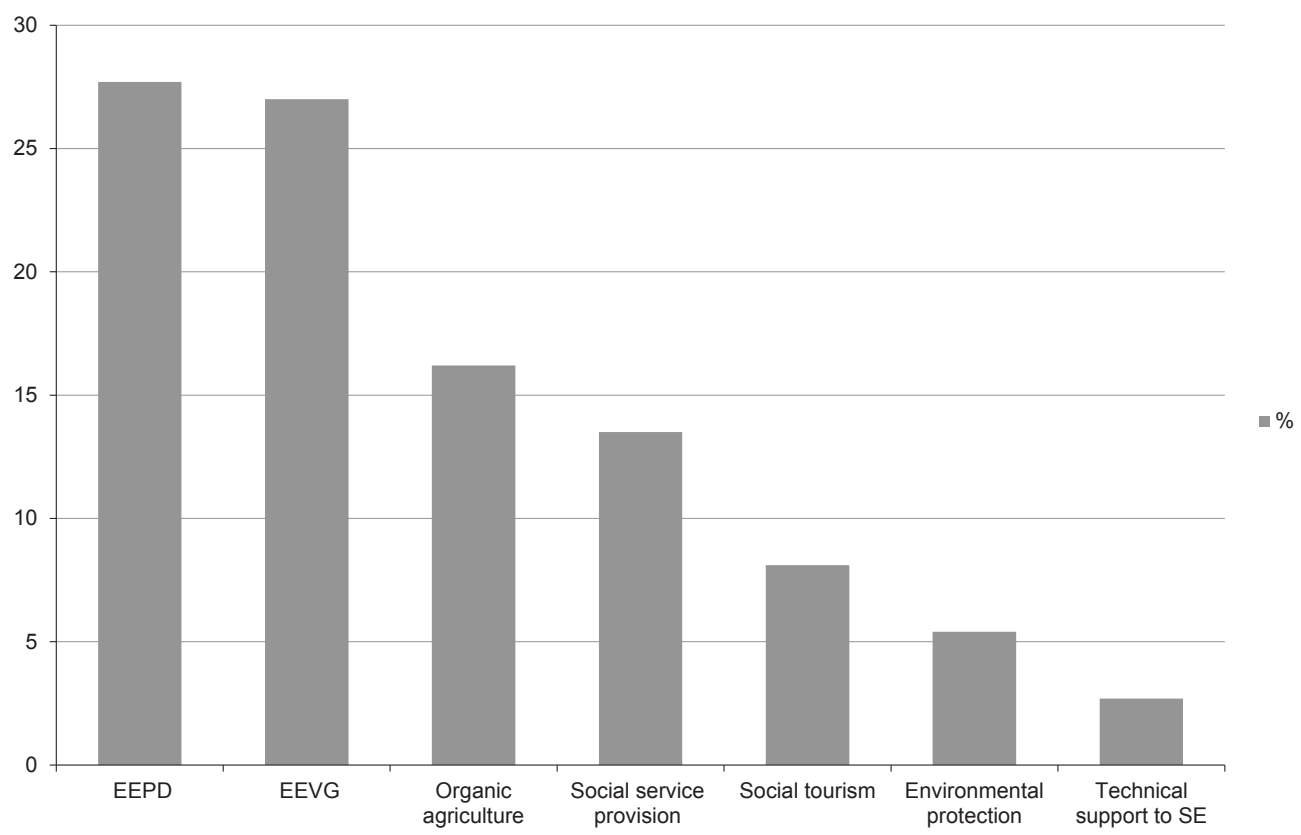

Source: Author's calculations.

The data presented in Figure 2 might suggest that a broader concept of social entrepreneurship - which entails social goals other than employment and social inclusion of vulnerable groups - is gradually taking hold. This finding also seems consistent with the results presented in Figure 3. In addition, a small number of SEs covered by the survey that engage in formal social service provision (those which fall within the list of social services recognized by law) might suggest that there is significant room for a greater role of SE to play in social service delivery.

A questionnaire which was prepared for the survey included the following questions: 1) how do you understand the concept of social entrepreneurship?; 2) what is your major source of income?; 3) do you measure social impact of your activities, and if so, how?; and, 4) what are the major challenges for your sustainability? As for the first question, the responses which SEs provided largely mirrored their stated social goals: out of 37 SEs surveyed, all EEPD identified the concept with their stated goals (11); the majority of associations engaged in the economic power and employment of other vulnerable groups also identified the concept with their stated goals (7 out of 10); while the rest of SEs surveyed perceived social entrepreneurship as a concept which includes broader social goals, beyond employment and economic empowerment of vulnerable groups (19). Despite these encouraging findings, given a relatively small sample of surveyed SEs, there still might be a need for additional awareness campaigns to highlight the potential social entrepreneurship can offer in addressing broadly 
defined social goals. A better understanding of the concept is necessary for SEs to forge more effective coalitions, speak in one voice, and advocate for comprehensive policy change which will impact positively on the SE sector across the board, rather than to focus on piecemeal reforms which would benefit only the few. source of income, with membership fees coming third; 5 SEs stated membership fees as a second source of income, with public funds coming third; and, 3 SEs stated foreign grants as the only source of income. None of the SEs surveyed cited corporate donations as a source of income. This seems to suggest that there is a need for greater

Figure 3

How SE understand the concept of social entrepreneurship

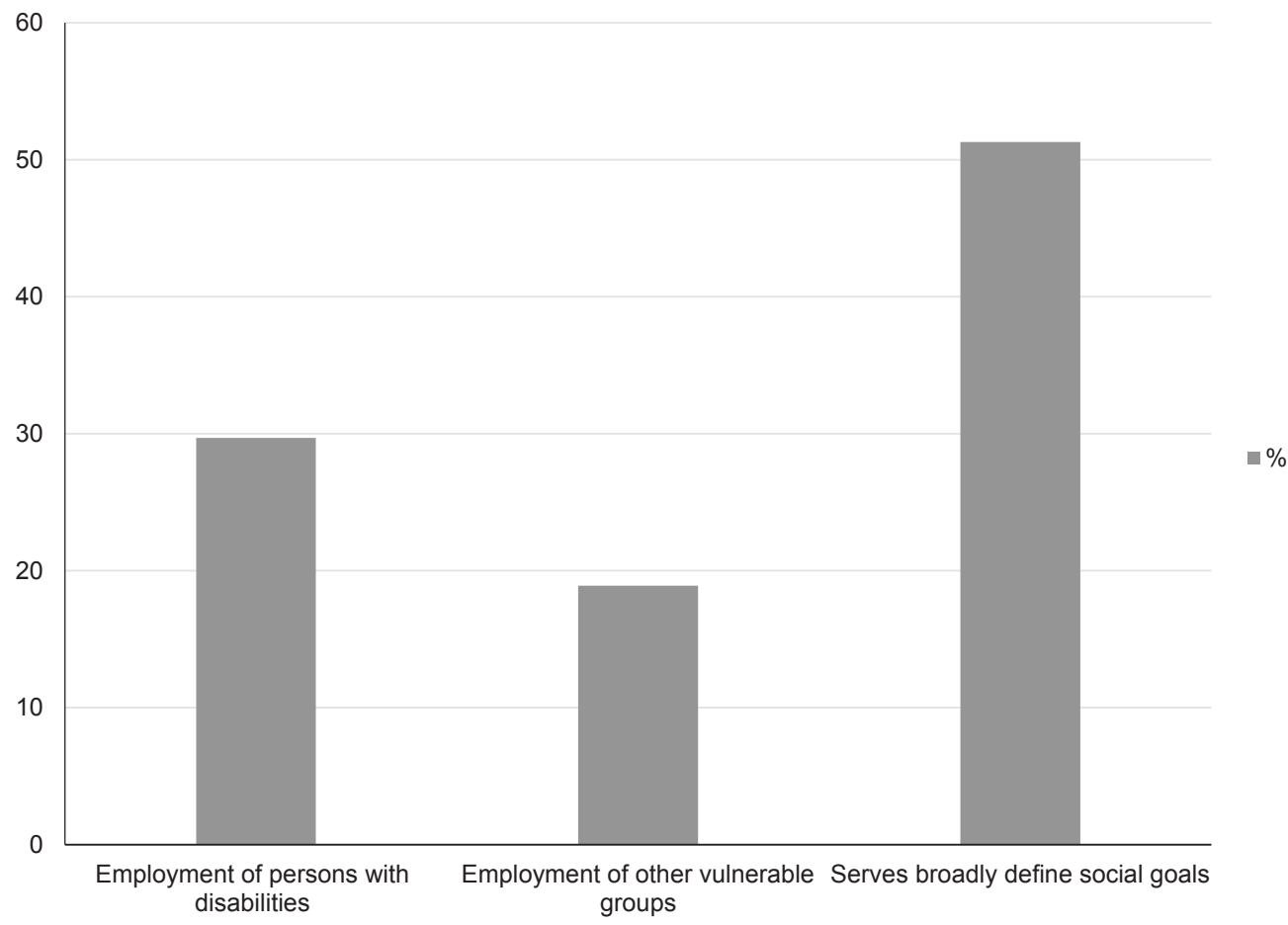

Source: Author's calculations.

As for the second question, 34 SEs stated economic activities as a major or the only source of income. This seems consistent with the very concept of SE and bodes well for a longer-term sustainability of the sector. 18 SEs cited public funds as a second awareness among SEs about the potential of utilising corporate social responsibility for social entrepreneurship initiatives, despite limited corporate income tax benefits which are currently available to support SE activities (Chapter 2). 
Figure 4

Major source of income for SE

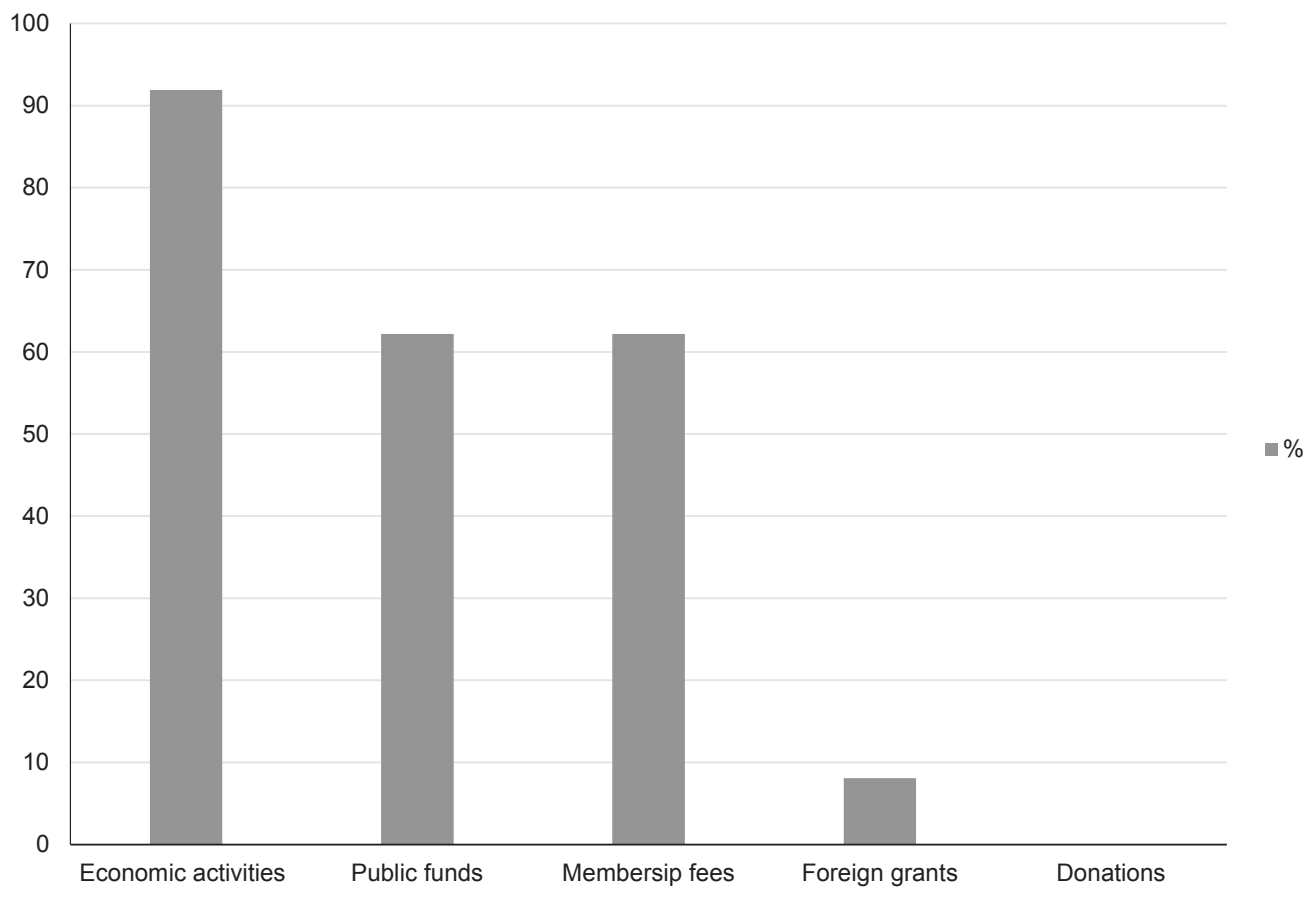

Source: Author's calculations.

With respect to challenges which SEs perceived as having a major impact on their sustainability, there was a rather striking difference in responses between the EEPD and the other surveyed. All EEPD (11) considered that the state aid available for their activities was insufficient, and a majority of EEPD (6 out of 10) also noted problems with timely distribution of state aid. These two groupings did not cite any other obstacles, such as lack of competitiveness or difficulties relating to ensuring access of their goods and services to the market. The rest of surveyed SE cited a variety of major challenges, and each of them cited at least two challenges. This included: the lack of framework regulation for SEs (16); the lack of state aid (11); the lack of specific tax benefits (10); the lack of access to start up funds (9); the lack of technical support (5); and, the regressive legal framework for volunteers (3). The received data might suggest that SEs are still predominantly concerned with receiving direct and indirect support from the state, rather than with honing the skills which would make them more competitive in the social market. 
Figure 5

Perceived major challenges for sustainability of SE

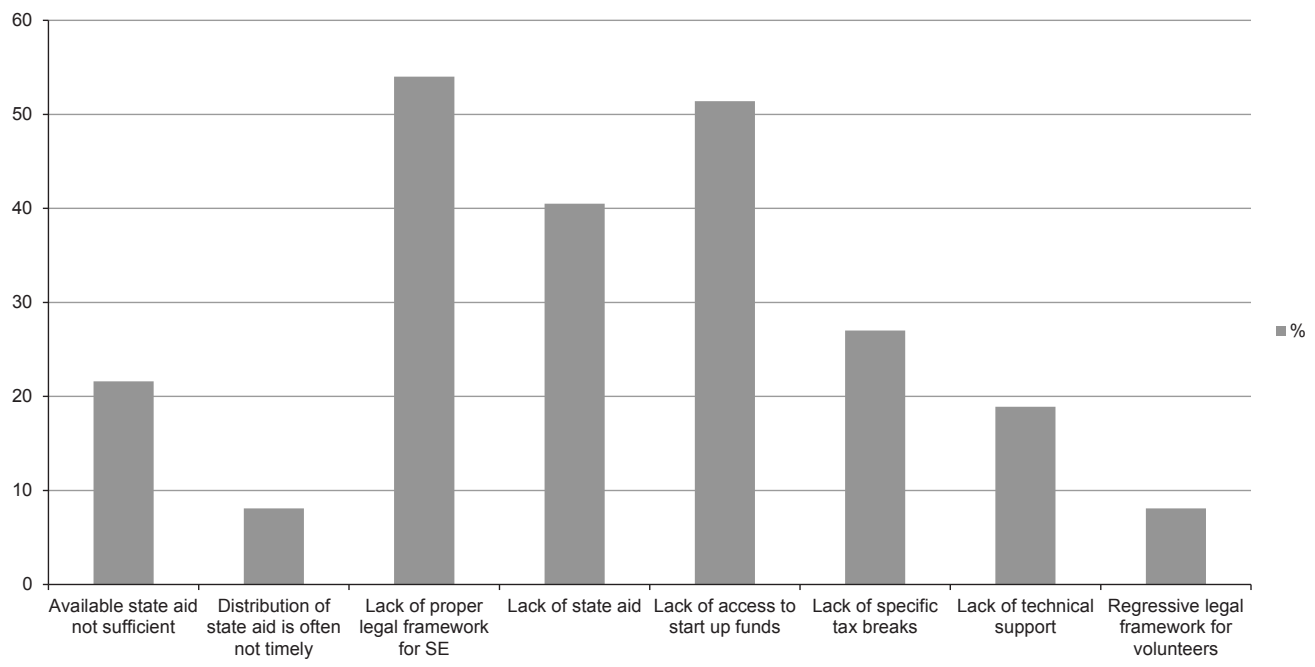

Source: Author's calculations.

Finally, none of the surveyed SEs measured social impact of their activities. Indeed, 25 out of 37 SEs were not familiar with the concept. The lack of social impact measurement and understanding of the concept does not necessarily come as a surprise, given that it is relatively a new concept. Measuring social impact requires a more mature social market and is often driven by government, donors or public procurement rules. In addition, there are significant differences of opinions as to how to measure social impact and whether there is a single applicable methodology in this respect (Clifford, Markey, Malpani, 2013; GECES, 2014; EC/OECD, 2015). Nevertheless, it seems important to raise awareness among SEs about the ensuing benefits of the social impact concept. Not least, it would help SE in their strategic planning and improving the quality of goods and services they provide - and would encourage them to be more accountable towards their respective constituencies (Ganz, Kay, Spicer, 2018).

\section{CONCLUSION}

The concept of social entrepreneurship in Serbia is steadily taking root in practice as well as on the policy level. With respect to the latter, the new framework regulation for CSOs and cooperatives has provided a menu of institutional tool of choice for SEs which is roughly comparable with best national practices (Wilkinson, 2015). However, there is still a lack of broader understanding of the concept, which is normatively reduced to the employment and betterment of persons with disabilities. Consequently, there is a lack of coherent strategy, including the necessary horizontal and vertical policy coordination, which would effectively promote the broader understanding of the concept. In addition, the framework regulation for CSO would benefit from clarifying 
conditions under which CSOs can engage directly in economic activities, in order to reduce the unwarranted discretionary power of the supervisory authority to decide on that issue. Furthermore, the notion of public benefit activities in the Corporate Income Tax Law is narrowly construed and falls short of recognising many activities in which SE traditionally operate as public benefit activities. The Law also falls short of recognising social entrepreneurship per se as a public benefit activity. This restrictive approach in tax law is not conducive to efforts to utilise the concept of corporate social responsibility for the promotion of social entrepreneurship. Furthermore, the regulation governing public funding to CSOs unduly discriminates against foundations and endowments, while the regressive legal framework for volunteering discourages SE from engaging volunteers in their activities, which impedes their sustainability.

Further development of social entrepreneurship in Serbia would benefit from introducing additional policy measures. However, it is paramount for those measures to be consistent with the need to preserve a "bottom-up" approach in the development of the sector. Given the controversy surrounding the concept, preserving the bottom-up approach is necessary in order for the government to determine the precise role SEs can play in solving pressing social needs, which otherwise fall within the remit of its responsibility. This seems particularly important, given that the access to the EU generous funds and bilateral assistance runs the risk of SEs following the money and catering to the needs of donors, rather than local communities they purport to serve. Those additional policy measures may include inter alia: creating a strategic framework for social entrepreneurship which would incorporate a broader understanding of the concept and ensure the necessary horizontal and vertical policy coordination as well as shared responsibilities among line ministries with respect to social entrepreneurship development, ensuring SEs access to start-up capital which is otherwise available to small and medium size enterprises, ensuring SEs access to business incubators so that they can benefit from gaining knowledge necessary to hone their skills and improve their competitiveness in the market, and introducing social entrepreneurship in the universities' curricula. In addition, a stronger networking between SEs, academics and practitioners seems necessary, in order to create a larger pool of knowledge which would facilitate articulation and implementation of policies supporting SEs. There is also a need for coalitions of SEs to take on a more active approach in raising awareness among policy makers about the meaning and underlying benefits of the concept, in particular at the local level. Likewise, there is a need for greater promotion and information sharing of SE best practices, in particular given the lack of viable business models to follow (Wilkinson, 2015).

Some of the foregoing proposed measures were envisaged in a draft National Strategy for the Development of an Enabling Environment for Civil Society in the Republic of Serbia 2015-2019, which is still pending before the Government..$^{17}$ The proposed measures are also consistent with the European Economic and Social Committee policy recommendations on SE, which put an emphasis on capacity building, access to start-up funds, information sharing, education and networking policy measures, rather than on further legal action and state intervention (EESC, 2014).

17 Since the original time frame envisaged for the duration of the Strategy was long past, it has been subseqently revised so as to cover the period from 2018 to 2020, as stipulated in the Goverment's Annual Plan for 2019. 
Finally, a thorough ex ante impact assessment is needed in order to determine the perceived benefits as well as the risks associated with introducing a framework regulation for SE. Arguably, such a measure would dispel, or at least abate, uncertainties as to precise characteristics of SEs and would thus facilitate design and implementation of sound policies geared at supporting social entrepreneurship. In addition, it would arguably reduce the risk of abusing the notion of SEs and would help identify potential investors in social undertakings. However, in countries which have introduced a framework regulation for SEs (Italy, Spain, Slovenia), there is still no conclusive evidence about the benefits associated with this particular policy approach (Golubovic, 2012; Trbanc, Polajner, 2013; Wilkinson, 2015). Moreover, introducing a framework regulation for SEs is not necessarily a guarantee that the concept will not be reduced to the employment and betterment of persons with disabilities and other vulnerable groups. This was reflected in a draft Law on Social Entrepreneurship and Employment in Social Enterprises, which the Ministry of Labour, Employment and Social Protection prepared in 2013. The draft was never tabled to Parliament, due to concerns raised in the preliminary public hearing that it reduced the concept of social entrepreneurship to the employment of specific segments of vulnerable population, and as such fell short of creating a general legal environment conducive to social entrepreneurship. ${ }^{18}$

\section{Acknowledgement}

This paper was prepared under the project: "Examining conditions and potential for development of social entrepreneurship as an instrument of social inclusion in the Autonomous Province of Vojvodina", implemented by the Educons University (project No. 142-451-3665-2016-02). The Government of the Autonomous Province of Vojvodina (Vajdaság Autonóm Tartomány) provided financial support to the project.

\section{REFERENCES}

Argyrou, A. (2017). Providing social enterprises with better access to public procurement: The development of supportive legal frameworks. European Procurement \& Public Private Partnership Law Review, 12(3), 310-324. https://doi. org/10.21552/epppl/2017/3/12

Austrian Institute for SME Research. (2007). Study on Practices and Policies in the Social Enterprise Sector in Europe: Final Report. Vienna: KMU Forschung.

Baron, P. D. (2007). Corporate social responsibility and social entrepreneurship. Journal of Economics and Management Strategy, 16(3), 683-717. https://doi.org/10.1111/j.1530-9134.2007.00154.x

Borzaga, C., \& Defourny, J. (2001). The emergence of social enterprise. London: Routledge.

Borzaga, C., Poledrini. S., \& Galera, G. (2017). Social enterprise in Italy: Typology, Diffusion and Characteristics. Euricse Working Papers No. 96. Available at https://www.euricse.eu/publications/ wp-9617-social-enterprise-in-italy-typology-diffusion-and-characteristics/

Byrne, N., McCarthy, O., \& O'Shaughnessy, M. (2004). A study of volunteerism in Irish credit unions and social enterprises. Cork: University College Cork.

Castles, G. F. (2004). The future of the welfare state: Crisis myth s and crisis realities. New York: Oxford University Press.

Centar za liberalno demokratske studije. (2013). Mapiranje usluga socijalne zaštite u nadležnosti lokalnih samouprava. Beograd: Centar za liberalno demokratske studije. Dostupno na http:// csp.org.rs/sr/publikacije

Chaves, R., \& Monzón, J. L. (2005). The social economy in the European Union. CIRIEC, No. CESE/ COMM/05.

\footnotetext{
${ }^{18}$ The most recent draft Law on Social Entrepreneurship, which the Ministry published in November 2018, has given rise to the same concerns: https://infobrif.rs/2018/11/17/nacrt-zakona-o-socijalnom-preduzetnistvu-sporan-i-problematican9913/vesti; accessed on November 11, 2018.
} 
Clifford, J., Markey, K., \& Malpani, N. (2013). Measuring social impact in social enterprise: The state of thought and practice in the UK. London: E3M.

Cornelius, N., Todres, M., Jivraj, S. J., Woods, A., \& Wallace, J. (2008). Corporate Social Responsibility and the Social Enterprise. Journal of Business Ethics, 81(2), 355-370. https://doi.org/10.1007/ s10551-007-9500-7

Defourny, J., \& Nyssens, M. (2010). Conceptions of social enterprise and social entrepreneurship in Europe and the United States: Convergences and divergences. Journal of Social Entrepreneurship, 1(1), 32-53. https://doi. org/10.1080/19420670903442053

Dokmanović, M., Koevski, G., \& Spasovski, D. (2016). Is social entrepreneurship achievable in Macedonia? An analysis of the historical background, potentials and perspectives for concept development. Revija za socijalnu politiku, 23(2), 197-213. https://doi.org/10.3935/rsp.v23i2.1308

European Commission. (2010). Buying Social! A guide to taking account of social considerations in public procurement. Brussels: European Commission.

European Commission. (2011). Social Business Initiative: Creating a favourable climate for social enterprises, key stakeholders in the social economy and innovation. (SEC(2011) 1278 final. Brussels: European Commission.

European Commission. (2016). Social enterprises and their eco-systems: Developments in Europe, Luxembourg: European Commission.

European Commission, \& Organisation for Economic Co-operation and Development. (2015). Policy Brief on social impact measurement for social enterprises. Luxembourg: European Commission.

European Economic and Social Committee. (2014). EESC Recommendations on Social Enterprise. Brussels: EESC.

European Foundation Centre. (2015). Comparative highlights of Foundations Law: The operating environment for foundations in Europe. Brussels: EFC.

Expert Group on Social Enterprises. (2014). Proposed approaches to social impact measurement in European Commission legislation and in practice relating to EuSEFs and the EaSI, Brussels: GECES.

Ferreira, J. J., Fernandes, I. C., Peres-Ortiz, M., \& Alves, H. (2017). Conceptualizing social entrepreneurship. International Review on Public and Nonprofit Marketing, 14(1), 73-93. https:// doi.org/10.1007/s12208-016-0165-8

Ganz, M., Kay, T., \& Spicer, J. (2018). Social enterprise is not social change. Stanford Social Innovation Review, (Spring), 59-60.

GHK. (2010). Volunteering in the European Union. London: GHK.

Golubović, D. (2012). Legal framework for social economy and social enterprises: A comparative report. Bratislava: United Nation Development Program, Budapest: European Center for Notfor-Profit Law.

Golubović, D., \& Galetin, M. (2015). Social entrepreneurship: A suitable instrument for addressing social policies in time of crises?. In Proceedings of Educons University, The Sixth International Science Symposium (pp. 261-273). Sremska Kamenica.

Hudson, R. (2009). Life on the edge: Navigating the competitive tensions between the 'social' and the 'economic' in the social economy and its relations to the mainstream. Journal of Economic Geography, 9(4), 493-510. https://doi. org/10.1093/jeg/lbp005

Joppke, C. (1987). The crisis of the welfare state, collective consumption, and the rise of new social actors. Berkeley Journal of Sociology, 32, 237-260. https://www.jstor.org/stable/41035366

Kerlin, A. J. (2010). A comparative analysis of the global emergence of social enterprise. VOLUNTAS: International journal of voluntary and non-profit organisations, 21(2), 162-179. https:// doi.org/10.1007/s11266-010-9126-8

Landin, S. A. (2009). Can the uncertainty caused by the questioning of tax measures in relation to cooperatives by the ECJ be solved?. CIRIEC Working Paper, No. 2014.

Monzón, C. J., \& Chaves, A. R. (2012). The social economy in the European Union. Brussels: EESC.

Münkner, H.-H. (2005). A comparative perspective on legal frameworks for the social economy. Marburg: University of Marburg.

Niño Silva, A. C. (2015). Social entrepreneurship and corporate social responsibility: Differences and points in common. Journal of Business \& Economic Policy, 2(2), 85-93.

O’Connor, C. H., \& Baker, R. (2017). Working with and for social enterprises: The role of the volunteer ethnographer. Social Enterprise Journal, 13(2), 180-193. https://doi.org/10.1108/SEJ-072016-0033 
Peredo, A. M., \& McLean, M. (2006). Social entrepreneurship: A critical review of the concept. Journal of World Business, 41(1), 56-65. https:// doi.org/10.1016/j.jwb.2005.10.007

Sandmo, A. (1995). Introduction: The welfare economics of the welfare state. The Scandinavian Journal of Economics, 97(4), 469-476. https:// doi.org/10.2307/3440538

Spear, R., \& Bidet, E. (2005). Social enterprise for work integration in 12 European countries: A descriptive analyses. Annals of Public and Cooperative Economics, 77(2), 195-231. https://doi. org/10.1111/j.1370-4788.2005.00276.x

Statistical Office of the Republic of Serbia. (2014). Economic impact of social enterprises in the Republic of Serbia. Available at http://socijalnouk- ljucivanje.gov.rs/wp-content/uploads/2014/06/ economic_impact_of_social_enterprises_in_ the_republic_of_serbia_RZS.pdf

Thomas, A. (2004). The rise of social cooperatives in Italy. VOLUNTAS: International Journal of Voluntary and Non-profit Organisations, 15(3), 243-262. https://doi.org/10.1023/B:VOLU.0000046280.06580.d8

Trbanc, M., \& Polajner, B. (2013). Experiences with social entrepreneurship in Slovenia sofar. Brussels: European Commission, Director General for Employment, Social Affairs and Equal Opportunities.

Wilkinson, C. (2015). A map of social enterprises and their eco-systems in Europe. Synthesis Report. Luxembourg: European Commission. 
Sažetak

SOCIJALNO PODUZETNIŠTVO U REPUBLICI SRBIJI: POSTOJEĆE STANJE

\author{
Dragan Golubović, Bela Muhi \\ Univerzitet Educons \\ Sremska Kamenica, Vojvodina, Srbija
}

\begin{abstract}
Ovaj rad razmatra glavna pitanja javnih politika od značaja za razvoj socijalnog (društvenog) poduzetništva u Republici Srbiji. Sastoji se od četiri poglavlja. Prvo poglavlje razmatra opći kontekst javnih politika značajnih za predmet istraživanja, prve institucionalne oblike socijalnih poduzeća, te čimbenike koji su odlučujuće utjecali na razvoj socijalnog poduzetništva u Republici Srbiji (RS) u zadnjih desetak godina. Rezultati prvog službenog istraživanja u području socijalnog poduzetništva u RS također se analiziraju u ovome poglavlju. U drugom poglavlju razmatra se pravni okvir koji izravno uređuje ili posljedično utječe na socijalno poduzetništvo u RS. Ovo se poglavlje sastoji od kritičke analize propisa koji uređuju poduzeća za profesionalnu rehabilitaciju i zapošljavanje osoba sa invaliditetom, pravni status organizacija civilnoga društva (OCD) i socijalnih zadruga, poreznih propisa značajnih za socijalno poduzetništvo, propisa koji uređuju sustav javnog financiranja OCD, javnih politika koje uređuju sustav socijalne zaštite, te propisa koji uređuju volontiranje. U trećem poglavlju predstavljeni su rezultati prvog pilot istraživanja socijalnih poduzeća koja djeluju u Autonomnoj Pokrajini Vojvodini, koje je provedeno 2016. godine. Zaključci o javnim politikama koje uređuju socijalno poduzetništvo u RS te mjerama koje bi mogle stimulativno utjecati na njegov dalji razvoj prezentirani su na kraju rada.
\end{abstract}

Ključne riječi: socijalno (društveno) poduzetništvo, socijalna poduzeća, organizacije civilnoga društva, poticajno pravno okruženje, istraživanje o socijalnim poduzećima. 